\title{
An Analysis on the Tendency of Pronunciation Made by Students with Indonesian Linguistic Background
}

\author{
Ranni Putri Stefani ${ }^{1}$, Ahmad Roba' $^{2}$ \\ ranni@mhs.teknokrat.ac.id ${ }^{1}$, ahmadrobai22@gmail.com² \\ Universitas Teknokrat Indonesia ${ }^{1,2}$
}

\begin{abstract}
The compulsory of speaking English to communicate at campus environment made the writers interested in the tendency of English pronunciation made by English students with Indonesian linguistic background. The question appeared was what kinds of difficulties that the learners face when they pronounce English words or when they speak in English. The objective was to find out the tendency of the mistakes they make. The data were collected by conducting direct observation in and outside classes. The talks or presentations made by the students were recorded. From the observation, the writers listed mispronounced words. The writers then used the words in written sentences and asked students to read those sentences. The students were also interviewed in order to have another measurement to determine the tendency occurring in the data. As results, most of the mispronunciation problems found were related to vowels, consonants and word stress. These are the most noticeable findings among other issues discovered after conducting the research.
\end{abstract}

Key Words: English, foreign language, mispronunciation, phonetics, phonology

\section{Introduction}

Speaking English at campus environment is a compulsory for English learners. Sometimes miscommunication cannot be avoided in their conversation. This problem is caused by mispronunciation among them. So, mastering pronunciation is one of important things in learning English. It is because different pronunciations will result in different meanings. Linguistic backgrounds will give impact on how they pronounce English words. It is thus interesting to know their tendency or problems which cause mispronunciation because this is usually found in conversations made by students with Indonesian linguistic background. They are still affected by their Indonesian style when pronouncing English words. One of recent studies about this influence of a mother tongue to a second language was that done on Bahasa Indonesia and one of its vernaculars (Gulö, 2017).

English can be one of languages that is difficult to master, especially the pronunciation. Vernick and Nesgoda stated that language learners may find difficulties in learning to speak English well because several spelling may be represented by a single sound (1980: xi). Mispronunciation becomes a common thing for those who are learning English especially those with Indonesian linguistic background. Therefore, this research is done to discover the tendency or problem that student face.

According to Crystal (1985), phonology is an aspect of linguistics which studies the sound system of language pronunciation is the most important in phonology. This means that mispronunciation can cause wrong meaning of words. Such consideration has become the reason for conducting this research. Major problems had been previously found by Renaldi, et al (2016) and this research aimed to discover further problems in details.

\section{Theory and Method}

As an author explains it, different types of studies will rely on different methodologies (Stake, 2010). The readers need to know whether the research was done quantitatively or qualitatively. Kothari says that the latter makes use of available facts or information to analyze and to make a critical evaluation (2004: 110). However, a complete description of the methods used enables the reader to evaluate the appropriateness of the methods and the reliability and the validity of the results.

The result of this research is in descriptive qualitative form. It means that the writers will deliver the result in sentences that describe the data in words in order to give conclusion for the research. The study focuses on the tendency of the mistakes when pronouncing English words. The data were collected by conducting direct observation in and outside classes and the talks or presentations made by the students were recorded. 
When doing the observation the writer tried to collect data as many as possible. After gathering the data from the observation, the writers listed mispronounced words, and then the writers used the words in written sentences and asked students to read those sentences.

\section{Findings and Discussion}

After conducting the observation and interview the researchers gathered the data and classified them into fourth main topics, there are vowels, consonants, stresses, and intonation. These topics represent the tendency of the students who made error pronunciations in English words. The students were also interviewed in order to have another measurement to determine the tendency occurring in the data. As results, most of the mispronunciation problems found were related to vowels, consonants, stresses, and intonation.

\section{Vowels}

When dealing with pronunciation, vowel is one of the most important parts of it. It is the color of word. Without it all words will look the same. When speakers utter vowels correctly, listeners will be able to directly understand the meaning but the opposite of this can influence the meaning of the words. Here, the researchers want to analyze the tendency of students with Indonesian linguistic background toward vowels.

\section{Close Mid Central Vowel}

The six words on this table represent vowel/a/ and demonstrate how the correct pronunciation is compared with the student's pronunciation. Students with Indonesian linguistic background, when pronouncing the words on the table have the tendency to pronounce them with Indonesian pronunciation.

\begin{tabular}{|c|c|c|c|}
\hline No. & Word & $\begin{array}{c}\text { Correct } \\
\text { Pronunciation }\end{array}$ & $\begin{array}{c}\text { Student's } \\
\text { Pronunciation }\end{array}$ \\
\hline 1 & balloon & / bə lu:n / & / ba lu:n / \\
\hline 2 & banana & / bə'na:nə/ & / ba'na:na/ \\
\hline 3 & material & / mə'tıriəl/ & / ma'tıriəl/ \\
\hline 4 & capacity & / kə'pæsəti/ & / kapasiti/ \\
\hline 5 & consider & / kən'sidər/ & / kon'sidər/ \\
\hline 6 & occur & / ə'k3:r/ & / o'k3:r/ \\
\hline
\end{tabular}

However most students with Indonesian linguistic background do not find difficulty in pronouncing /a/ because Indonesian has vowel /o/. Although not all students with Indonesian linguistic background make mistake when pronouncing the words, but when observing them, almost all of them have the tendency when seeing $a$ letter unconsciously pronouncing it with Indonesian pronunciation. Further examples can be seen in (5) and (6).

\section{Near-Open Front Unrounded Vowel}

Another sound that is often mispronounced by the students with Indonesian linguistic background is /æ/. Their pronunciation often falls to Indonesian alphabet $a$ or $e$ because vowel /æ/ never used in Indonesia.

\begin{tabular}{|c|c|c|c|}
\hline No. & Word & $\begin{array}{c}\text { Correct } \\
\text { Pronunciation }\end{array}$ & $\begin{array}{c}\text { Student's } \\
\text { Pronunciation }\end{array}$ \\
\hline 7 & pass & / pæs / & /pəs// \\
\hline 8 & after & /'æftər/ & /'aftər/ \\
\hline 9 & sample & /'sæmpl/ & /'səmpl/ \\
\hline 10 & action & /'æk/n/ & /'2k/n/ \\
\hline 11 & happen & /'hæpən/ & /'həpən/ \\
\hline 12 & jacket & /'dzækit/ & /'dzəkıt/ \\
\hline
\end{tabular}

The table above gives examples of some words using /æ/ vowel sound. When they pronounce/æ/, they replace it by /a:/ or /ə/. Like in number (7) some students tend pronounce /æ/ with /ə/ and in number (8) they tend to replace it with long vowel /a:/. 


\section{Near Close Front Unrounded Vowel}

The other vowel sound mispronounced by students with Indonesian linguistic background is /I/. The table below gives examples of words using $/ \mathrm{I} /$. The sound is short and low and the position of the tongue is in the middle. It does not touch the top front of the mouth.

\begin{tabular}{|c|c|c|c|}
\hline No. & Word & $\begin{array}{c}\text { Correct } \\
\text { Pronunciation }\end{array}$ & $\begin{array}{c}\text { Student's } \\
\text { Pronunciation }\end{array}$ \\
\hline 13 & it & $/ \mathrm{it} /$ & /it/ \\
\hline 14 & in & $/ \mathrm{In} /$ & /in/ \\
\hline 15 & is & $/ \mathrm{IZ} /$ & /iz/ \\
\hline 16 & if & $/ \mathrm{If} /$ & /if/ \\
\hline 17 & ill & /Il/ & /il/ \\
\hline 18 & imitate & /'Imitert/ & /imitət/ \\
\hline
\end{tabular}

While observing students' presentations and watching the recordings, the researchers found mispronunciation producing / / / sound in simple words like $i t$, in and $i$. The factor why students with Indonesian linguistic background fail to recognize this sound is because the vowel does not exist in Indonesian. Therefore students fall into sound /i/ when they see letter $i$ like in number (17) and (18). In contrary, English words do not always use /i/ sound.

\section{Consonants}

Recently, there was a research done by Renaldi (2016) related to pronunciation errors of consonant sounds. They found that English learners tend to produce errors in pronunciation of some English words, mainly in consonant sounds. In this paper, the researchers also found that the students make mistakes in pronunciation of consonant sounds. However, they also face other problems like in vowels, stresses, and intonations. The analysis below shows the student's tendency in pronouncing words which contain consonant sounds, as further findings related to the previous one. The words listed are common words that the students mispronounce the most.

\section{Voice Alveolar Fricative}

Voiced alveolar fricative sound /z/ inside English words sometimes makes the students confused because it can be represented by letter $s$ or $z$ in the words. The table shown below is the result on how the students pronounce the words which contain letter $s$, and they still pronounce them as phoneme $/ \mathrm{s} /$ when it should be $/ \mathrm{z} /$.

\begin{tabular}{|c|c|c|c|}
\hline No. & Word & $\begin{array}{c}\text { Correct } \\
\text { Pronunciation }\end{array}$ & $\begin{array}{c}\text { Student's } \\
\text { Pronunciation }\end{array}$ \\
\hline 19 & rose & / rovz / & $/ \operatorname{ros} /$ \\
\hline 20 & cheese & / t fi:z/ & $/ \mathrm{t} \int \mathrm{i}: \mathrm{s} /$ \\
\hline 21 & bees & / bi:z/ & / bi:s/ \\
\hline 22 & poison & / 'porzn/ & / 'poisn/ \\
\hline 23 & raisin & / 'reIzn/ & /'reIsn/ \\
\hline 24 & desert & / 'dezərt/ & / 'desort/ \\
\hline
\end{tabular}

From the table above, the students with Indonesian linguistic background show difficulty in pronouncing /z/ in word (19), (20) and (21) when the phoneme /z/ is placed in the final as well as words (22), (23) and (24) when the phoneme /z/ is placed in the middle. Many words in Indonesian contain phoneme /z/ in the initial like zaman, zat, zaitun, etc. so there is no difficulty when they pronounce phoneme $/ z /$ if it is placed at the beginning of the words. In the words listed above, there is no letter $z$ which usually represents the phoneme /z/, so the students tend to pronounce it as phoneme $/ \mathrm{s} /$.

\section{Voiced Alveolar Stop}

Another problem is in voiced alveolar stopped sound. Most pronunciation problems occur when the phoneme is placed in the final as seen in the table below. 


\begin{tabular}{|c|c|c|c|}
\hline No. & Word & $\begin{array}{c}\text { Correct } \\
\text { Pronunciation }\end{array}$ & $\begin{array}{c}\text { Student's } \\
\text { Pronunciation }\end{array}$ \\
\hline 25 & odd & $/ \mathrm{a}: \mathrm{d} /$ & $/ \mathrm{a}: \mathrm{t} /$ \\
\hline 26 & seed & $/ \mathrm{si} \cdot \mathrm{d} /$ & $/ \mathrm{si} \cdot \mathrm{t} /$ \\
\hline 27 & mud & $/ \mathrm{m} \Lambda \mathrm{d} /$ & $/ \mathrm{m} \Lambda \mathrm{t} /$ \\
\hline 28 & $\mathrm{sad}$ & $/ \mathrm{sæd} /$ & $/ \mathrm{sæt} /$ \\
\hline 29 & land & $/ \mathrm{læn} /$ & $/ \mathrm{mæt} /$ \\
\hline 30 & mad & $/ \mathrm{mæd} /$ & \\
\hline
\end{tabular}

The words on the table above contain phoneme /d/ which is categorized as voiced alveolar stop. Students have no difficulty when pronouncing words with phoneme /d/ when it is placed in the initial or middle. The problem is when it is placed in the final position. The students tend to pronounce it as $/ \mathrm{t} / \mathrm{when}$ it is placed in the final because they do not give an emphasis on the phoneme /d/ in the final of the word, so that they pronounce it as /t/ while it should be /d/. This can cause misunderstanding when students say words like seed /si:d/ as /si:t/ in datum (26) because what people will get is the word seat rather than seed.

\section{Voiced Velar Stop}

The sound from velar point is produced when touching the back of the tongue to the palate. It can produce sound $/ \mathrm{k} /, / \mathrm{g} /$ and $/ \mathrm{y} /$. Here, the researchers only focused on the sound $/ \mathrm{g} /$ which is produced by the students as seen on the table below.

\begin{tabular}{|c|c|c|c|}
\hline No. & Word & $\begin{array}{c}\text { Correct } \\
\text { Pronunciation }\end{array}$ & $\begin{array}{c}\text { Student's } \\
\text { Pronunciation }\end{array}$ \\
\hline 31 & bag & $/ \mathrm{bæg} /$ & $/ \mathrm{bæk} /$ \\
\hline 32 & tag & $/ \mathrm{tæg} /$ & $/ \mathrm{tæk} /$ \\
\hline 33 & snag & $/ \mathrm{snæg} /$ & $/ \mathrm{snæk} /$ \\
\hline 34 & jug & $/ \mathrm{d} 3 \wedge \mathrm{g} /$ & $/ \mathrm{d} 3 \wedge \mathrm{k} /$ \\
\hline 35 & gap & $/ \mathrm{gæp} /$ & $/ \mathrm{gæp} /$ \\
\hline 36 & great & $/ \mathrm{greIt} /$ & $/ \mathrm{gret} /$ \\
\hline
\end{tabular}

The students do not have difficulty in pronouncing $/ \mathrm{g} /$ when it is placed in the initial as seen in word (35) and (36), but it is different when the sound /g/ is placed in final position as in words (31), (32), (33) and (34). They do not give an emphasis at the end of the word they pronounce so that the sound changes into $/ \mathrm{k} /$ sound while it should be /g/ sound. It can be also influenced by their linguistic background since it is rare in Indonesian to find words with sound $/ \mathrm{g} /$ at the ends.

\section{Labiodental Fricative}

There are 2 phonemes that can be produced from labiodentals: voiceless fricative phoneme /f/ and voiced fricative phoneme $/ \mathrm{v} /$. The problem is similar to alveolar fricative sound $/ \mathrm{s} /$ and $/ \mathrm{z} /$. The students tend to make mistake when pronouncing words similar to the listed ones on the table below.

\begin{tabular}{|c|c|c|c|}
\hline No. & Word & $\begin{array}{c}\text { Correct } \\
\text { Pronunciation } \\
\end{array}$ & $\begin{array}{c}\text { Student's } \\
\text { Pronunciation }\end{array}$ \\
\hline 37 & twelve & / twelv / & / twelf / \\
\hline 38 & vegetable & / 'ved3təb/ & / 'fed3təb/ \\
\hline 39 & vacation & / va'kerfn/ & / fo'keIfn/ \\
\hline 40 & value & / 'vælju:/ & / 'fælju:/ \\
\hline 41 & various & / 'verias/ & / 'ferias/ \\
\hline 42 & version & / 'v3:rzn/ & / 'f3:rzn/ \\
\hline
\end{tabular}

Seen from the table above, the students tend to change phoneme /v/ into /f/. It is because in Indonesian, it seems like there is no different in pronouncing phonemes /f/ and /v/. So students with Indonesian linguistic background tend to change phoneme /v/ to /f/ when /v/ is placed in the initial as seen in words (38) through (42) 
and final of the word like in (37). They may probably do the same thing if they find the words with phoneme $/ \mathrm{v} /$ in the middle like savannah since it is also rare to find Indonesian words with phoneme $/ \mathrm{v} /$ in the middle.

\section{Word Stress}

Word stress is the key to understand spoken English. Native speakers use word stress naturally because they grow with it. It is so natural for them so that they don't even know they use it. Taken from englishclub.com (2016), non-native speakers who speak English to native speakers without using word stress, encounter two problems:

1. They find it difficult to understand native speakers, especially those speaking fast.

2. The native speakers may find it difficult to understand them.

Here, the writers found out that students with Indonesian linguistic background also have problem with word stress, when observing the presentations delivered by the students they almost never use word stress or they use it incorrectly.

\begin{tabular}{|c|c|c|c|}
\hline No. & Word & $\begin{array}{c}\text { Correct } \\
\text { Stress }\end{array}$ & $\begin{array}{c}\text { Student's } \\
\text { Stress }\end{array}$ \\
\hline 43 & teacher & / 'ti:tృr/ & / ti:tjər/ \\
\hline 44 & japan & /dzə'pæn/ & /dzəpæn/ \\
\hline 45 & photo & /'fou.tou/ & /fou.tou/ \\
\hline 46 & photographer & / fə'ta:grəfər / & / fəta:grəfər / \\
\hline
\end{tabular}

Seen from table above, students with Indonesian linguistic background tend to not use stress on certain syllables. They do not know how to use word stress. Each word is different like in word (45), Japan, the stress is in the last syllable -pan, and if we look at (46) and (47), even both words contain word photo, it does not mean they have the same stress position. In (46) the stress is in the first syllable meanwhile in (47) the stress is in the second syllable -to- while the rest syllables are not stressed.

\section{Conclusion}

From the discussion above, it can be concluded that mispronunciation problem is related to pronunciation of vowel and consonant sounds. However, the data shown are the most common words that the students tend to pronounce incorrectly. The cause of mispronunciation is their linguistic background and their hearing people pronouncing the words incorrectly. By knowing that students tend to make mistakes in pronouncing those words, both the learners and teachers should give more attention to the sounds which cause most mispronunciations so that the problem can be avoided.

\section{References}

Crystal, D. 1985. A Dictionary of Linguistics and Phonetics. Oxford: Basil Blackwell Ltd.

English Club. ----. Word Stress. https://www.englishclub.com/pronunciation/word-stress.htm. (Retrieved on September 19, 2016)

Gulö, Ingatan. 2017. Turu huja, kai basa semua: Nias version of bahasa Indonesia. Konferensi Lingusitik Tahunan Atma Jaya 15. Jakarta: Pusat Kajian Bahasa dan Budaya Universitas Katolik Indonesia Atma Jaya

Kothari, C.R. 2004. Research Methodology: Methods and Techniques. New Delhi: New Age International Publishers.

Muniem, Fazle. 2015. How English learners can improve intonation. https://www.britishcouncil.org/voicesmagazine/how-english-learners-can-improve-intonation. (Retrieved on September 19, 2016)

Philomath. 2011. English sounds for Indonesian speakers. http://theloveroflearning.blogspot.co.id/2011/02/english-sounds-for-indonesian-speakers.html. (Retrieved on September 19, 2016) 
Renadi, Ahmad, Ranni P. Stefani, \& Ingatan Gulö. 2016. 'Phonological Difficulties Faced by Students in Learning English'. Proceedings of the Fourth International Seminar on English Language and Teaching (ISELT 4). Padang: Universitas Negeri Padang.

Stake, Robert E (ed.). 2010. Qualitative Research: Studying How Things Work. New York: The Guilford Press.

Vernick, J., \& Nesgoda, J. 1980. American English Sounds and Spellings for Beginning ESL students. Pittsburgh: University of Pittsburgh Press. 